\title{
INTERACTIVE LEARNING AND CAPABILITY-BUILDING IN CRITICAL PROJECTS
}

\author{
Rebecca Hanlin and Josephat Mongare Okemwa
}

\begin{abstract}
This chapter investigates how wind and solar energy parks (large and small) provide opportunities to build capabilities that have the potential to enable more inclusive economic and social development in Kenya. It analyses what types of capabilities are built through renewable energy projects and asks whether the size and shape of a project is important to the opportunities to build capabilities. It finds that size of the project is important but that valuable capabilities are built in both large- and small-scale renewable electrification projects. It finds that across both large and small projects, a specific set of capabilities are important: linkage capabilities or a series of dynamic capabilities at the strategic level relating to project management. The findings raise interesting questions on the way projects are designed and managed and the need for more research on the relative merits of different types of project management contracts. This has implications for the way policy is promoted not just in skills development but also local content rules and the wider issue of export-oriented sustainable industrialisation.
\end{abstract}

\section{Introduction}

The interest in wind and solar as alternative energy sources is predominately related to the need to increase energy access and particularly clean energy access. However, this chapter starts from a different hypothesis. We hypothesise that the promotion of wind and solar on- and off-grid energy projects, in addition to providing opportunities for improved clean energy access, has a valuable role in contributing to the economic growth and development of the country.

African countries are increasingly promoting large infrastructure projects with the hope of boosting economic development (Africa Renewable Energy 
Initiative, 2016a). For example, the Kenyan Vision 2030 puts infrastructure among the key pillars that anchor economic progress. Therefore, the strategy puts infrastructure development as a key priority of action (Government of the Republic of Kenya, 2007). The more recent 'Big Four Agenda', which is now driving all government policy initiatives in Kenya, requires energy as an enabler of the four focus areas of growth (manufacturing, food security, universal health coverage, and affordable housing) (Hoka, Njogu, and Obiero, 2018).

There is a large body of evidence that shows a positive relationship between infrastructure development, economic growth, and development (for example, Calderon and Serven, 2010; Démurger, 2001; Khandker, Bakht, and Koolwal, 2009). Despite this, little research exists on the role solar and wind energy infrastructure, specifically, plays on economic growth. This chapter is therefore interested in understanding - through the investigation of various critical case studies - the ways in which renewable energy projects, both on- and off-grid, contribute to economic growth and development. We investigate how projects do this by building different types of capabilities within local firms through the opportunities afforded by collaborations with external and internal actors. These opportunities might be an explicit part of a collaborative agreement between two firms, a publicised commitment, or objective of one of the project partners or related stakeholders, or it could occur more implicitly as an 'added extra' as a result of routine project activities.

With the increased recognition of the importance of local content and local capacity building, such issues have now entered the policy discourse in Kenya. The revised Energy Act (2019) specifies the need for the development of local capabilities to manufacture, install, and maintain renewable technologies (clause 44 (1)(o)). In addition, the Act gives the Energy and Petroleum Regulatory Authority (EPRA) the authority to enforce local content requirements including the use of Kenyan contractors and Kenyan staff where qualified and skilled staff/ companies are available. Firms involved in energy production are also expected to submit annual and long-term local content plans.

As such, this chapter asks the question; 'what types of capabilities are built at national level through the design and construction of renewable energy infrastructure projects in Kenya?' It further asks; 'how does the way a project is designed and managed impact on capability-building?' Through asking these questions, and discussing data collected from a review of four renewable energy solar and wind projects in Kenya (two large and two small scale), this chapter identifies areas where capabilities are built that could provide long-term opportunities for improved economic development in Kenya.

\section{Why capability-building through projects?}

\section{Projectisation of the Kenyan energy sector}

Kenya's attempts to use renewable energy supplies to 'reach the last mile' and improve energy access focuses on a range of different renewable energy strategies, 
some involving large-scale on-grid projects using solar and wind technology and other off-grid solutions. The development of these usually operates using a 'project' approach; the design, installation, and operation of the renewable technologies are managed by one lead partner and can involve a series of other partners to provide technological or other inputs as needed. This approach is very different to vertically integrated government infrastructure projects for energy electrification.

In fact, the move away from vertically integrated government infrastructure projects has taken place over the last 20 plus years in a range of sectors across the globe. The most often discussed examples are in health and education. Although very well researched in high income countries, the change in focus has been felt in Africa too with the rise of public-private partnerships and contracting out of service provision in various sectors (Liu, Hotchkiss, and Bose, 2008; Farlam, 2005).

The idea of 'project management' as a concept and practice has become very well established in the last 30 years (although the concept and approach started in the 1930s and 1940s with military and process engineering in the United States (Brady and Hobday, 2011)) and is seen by many as an important tool in ensuring projects - of all types - are managed effectively. Brady and Hobday (2011) refer to one project management style of 'project business' which has taken hold since the late 1990s and is focused on the creation of new markets through project activities.

Davies and Brady (2016) identify two types of projects in relation to dynamic capabilities: 'routine projects' and 'innovative projects'. Routine projects are projects that utilise existing and mature products and technologies to satisfy current customer demands. These types of projects require traditional and routine forms of project management capability. Their major strength is exploiting the 'economies of repetition'. Innovative projects, on the other hand, aim at identifying and experimenting with new ideas and approaches that create entirely new market segments, technologies, products, services, and approaches. These are highly risky and unpredictable endeavours being difficult to plan. Such projects require novel ways of organisational planning and a complete shift from existing and prior project routines and capabilities both at the strategic and operational levels (Davies and Brady, 2016).

\section{Key to all is capabilities at project level}

To study how project business successfully builds local capabilities places a focus not just on the ability to conduct routine firm related technology and business management but also focuses on a firm's ability to manage relationships with other firms involved in the project (either in their role as project manager or member of the project team). This requires not just firm level capabilities-building (firm and individual) but linkage level capabilities (Lall, 1994).

Bell (2009) sums up his understanding of the capabilities needed into two types of technological capabilities; first, that which is required for ongoing 
operations with existing forms of technology already in use (the routine technology and business management routines mentioned above). These capabilities are referred to in the literature as 'production capabilities'. The second type of capabilities referred to by Bell is that of 'innovation capabilities' or the ability to recognise the need for different forms of technology that are not currently in use in the firm.

In this context, the term 'technology' is not just referring to physical products but also to a range of different forms of knowledge. Archibugi and Coco (2005) group technological capabilities into three different sets of contrasts:

1. Either embodied physical technologies or disembodied technologies or knowledge.

2. Either codified or tacit in nature with regard to the degree to which the product or knowledge can be easily understood through written instructions, plans, or diagrams.

3. About generation and/or about diffusion of products and knowledge. Not all firms will generate new or modified technologies or knowledge but will gain new capabilities through the use of technologies and knowledge developed by others.

Others (see Hansen and Ockwell, 2014) focus on a continuum of technological capabilities from production through to innovation and focus on the way firms change from being able to conduct capabilities that are new to the firm, through to those that are new to the market and eventually to those that are new to the world i.e., ever increasing levels of innovativeness.

\section{Technological capabilities and competitiveness}

The development of technological capabilities provides firms with means to become increasingly competitive. There are two parts to this argument. First, that export-oriented firms are more likely to develop more relevant technological capabilities than those that are focused on a national market. Lall (1994) argues that inward-oriented firms learn to 'make do' or 'stretch' available resources while those that are outward looking try to reduce costs, raise quality, and introduce new knowledge.

Interestingly, a set of literature that has become prominent in the innovation and development field more recently argues that innovation in scarcity conditions is a positive attribute (regardless of a firm's outward or inward looking orientation), because it usually ensures that only those innovations and related capabilities are built that are needed by society (Srinivas and Sutz, 2006).

The second set of arguments here relate to the global value chains literature and are linked to the arguments of Lall above. The overarching argument of this literature is that developing country firms would benefit from insertion into global value chains and global production networks. This literature focuses on 
two main areas of thinking that are relevant here: (i) upgrading within the firm (process, product, or function) or (ii) linkage creation and capabilities-building/ upgrading along the chain (Haakonsson, 2009). We are interested in both but assume the first as a result of the second. Therefore, our primary interest is the second focus area. In addition, the focus of global value chain literature is predominately on upgrading in firms or linkages between firms because of exporting activity, but it is actually possible to learn from importing (Haakonsson, 2009). It is learning through importing that we are interested in.

\section{Methodology}

We focused specifically on several indicators for the assessment of capabilities and upgrading (see Table 7.1). We chose these based on a literature review undertaken (see Hanlin, Okemwa, and Gregersen, 2020).

TABLE 7.1 Indicators to be used to assess capabilities and upgrading

\begin{tabular}{|c|c|c|}
\hline $\begin{array}{l}\text { Inputs and } \\
\text { outcomes }\end{array}$ & $\begin{array}{l}\text { Capabilities and } \\
\text { upgrading }\end{array}$ & Indicators \\
\hline $\begin{array}{c}\text { Micro-level } \\
\text { inputs }\end{array}$ & Individual skills & $\begin{array}{l}\text { 1. Government minimum standards } \\
\text { 2. Additional 'on the job' skills identified } \\
\text { 3. Training opportunities }\end{array}$ \\
\hline $\begin{array}{l}\text { Meso-level } \\
\text { inputs }\end{array}$ & $\begin{array}{c}\text { Technological } \\
\text { capabilities }\end{array}$ & $\begin{array}{l}\text { 4. New physical technologies (e.g., new piece } \\
\text { of testing equipment) introduced into the } \\
\text { firm that results in new business opportuni- } \\
\text { ties at any stage in the project cycle } \\
\text { 5. New knowledge introduced into the firm } \\
\text { that results in new business opportunity at } \\
\text { any stage in the project cycle (e.g., recruit- } \\
\text { ment of a staff member with EPC experience } \\
\text { or training of existing staff in how to install a } \\
\text { specific new invertor design) }\end{array}$ \\
\hline & Core competences & $\begin{array}{l}\text { 6. Function as an EPC contractor } \\
\text { 7. Evidence of ability to leverage new partner- } \\
\text { ships on the back of previous work }\end{array}$ \\
\hline Outcomes & Upgrading & $\begin{array}{l}\text { 8. Process upgrading (e.g., increased efficiency } \\
\text { of installation process - speed/ manpower } \\
\text { requirement) } \\
\text { 9. Product upgrading (e.g., from using Chinese } \\
\text { to German inverters) } \\
\text { 10. Functional upgrading (e.g., move from being } \\
\text { a contractor to doing full EPC) } \\
\text { 11. Chain upgrading (e.g., move from installing } \\
\text { solar heaters to installing mini-grid systems) }\end{array}$ \\
\hline
\end{tabular}


We chose to study these indicators through a few case studies of renewable electrification projects in Kenya. These cases were chosen based on a review of the answers given to a question 'what have been the most important energy projects for Kenya in the last ten years?' during a survey conducted as part of the IREK project (Andersen et al., 2017). This survey found that Lake Turkana Wind Power (LTWP) Project was the most frequently cited large-scale project. For small projects, the survey identified the most frequently named project as Kitonyoni solar project (13.5 Kwp). In addition, we decided to choose a small number of mixed projects in terms of characteristics or what are sometimes referred to as 'maximum variation cases' (Flyvbjerg, 2006). As a result, we chose a selection of projects that differed in terms of the origin of the equipment, the project size, focus energy source, and grid connectivity. Further differences included: different sized lead firms, different organisational project set-ups, different investors, and different locations. Our final four case studies in Kenya were: LTWP, Kitonyoni solar project, Garissa solar park, and SOS Children's Village solar park in Mombasa.

While ideally we would have liked to have included a large-scale solar offgrid and a small-scale wind on-grid project, unfortunately we found it difficult to identify suitable project candidates in these two categories. The difficulties of finding small-scale wind projects in Kenya have been noted elsewhere (Wandera, this volume).

\section{Research methods}

We employed qualitative research methods to study these four projects. The methods used a combination of desk review of materials, observation, and interviews. While colleagues (Nzila and Korir, this volume) have utilised surveys to identify types of capabilities built in projects; qualitative methods provide us with the opportunity to explore the 'why' questions relating to capability-building. We recognise that, unlike with a survey approach, we are unable to argue that the findings are necessarily anything other than unique for the projects we have studied. We believe they provide important insights into how capabilities through project business are created for those conducting project activities in these areas and for those designing policies to encourage local content development. Full details of the research methods and data analysis techniques used are provided in Hanlin, Okemwa, and Gregersen (2020).

\section{The projects introduced}

The first large-scale project that we studied was LTWP project. The construction of the project was started in October 2014, and it was commissioned in November 2018. It is a 310-megawatt wind power park. The project is owned by a Kenyan registered company, the Lake Turkana Wind Power Ltd, 
with financing from a range of sources (local and international) and has a 30 -year power purchasing agreement with the Kenyan electrical utility company. Engineering, procurement, and construction was managed through an Engineering Procurement and Construction Management (EPCM) ${ }^{1}$ contract given to a South African branch of a global engineering project management firm, Worley Parsons. A range of different firms were then contracted for various project elements. Many of these firms were from Kenya or East African countries but during construction of the wind turbines two external firms (one Danish, Vestas, and one Greek, Anopsitiki) conducted most of the work. That said, Anopsitiki did work with a local Kenyan firm (SECO Engineering) using their equipment and personnel to assist them in erecting the turbine towers, and Vestas has trained up local engineers to conduct maintenance on the turbines during the operational phase of the project (despite having originally expected to need to use expatriate staff to operate and maintain the equipment). Other local or regional firms were contracted to conduct the groundwork and camp building (SECO), road construction (Civicon), and wind turbine plinth construction (Entreprise Générale Malta Forrest). The wind turbine technology was Danish with production done in the Vestas' manufacturing facilities in China. Other major equipment and technology was also sourced externally although locally produced consumables were utilised during the project construction period.

The second large-scale project that we studied was the Garissa solar park. It is a 55-megawatt park and was the result of an agreement with the government of Kenya and China signed in 2013. The construction of the project was started in January 2017 and the park was commissioned in October 2018. Rural Electrification and Renewable Energy Corporation (REREC), formerly known as Rural Electrification Agency (REA) have a 25-year power purchase agreement with Kenya Power at 5 KShs/KWh. REREC have contracted the Kenyan national electricity provider, KenGen, to operate the plant. Project financing was through China's EXIM bank. China Jiangxi Corporation for International Economic and Technical Cooperation Company (CJIC) were given an EPC (engineering, procurement, construction contract) to build the plant but did utilise a local firm (Maknes Consulting) as the local site agent and CJIC have trained up staff of REREC to operate the facility while still providing technical support for the first two years. Very few other Kenyan firms were involved other than a transporter (Landmark Port Conveyers) contracted to bring panels and stands to site. All equipment used was Chinese in origin other than some locally purchased consumables.

The first small-scale project studied was SOS Children's Village in Mombasa. The project idea was conceived in 2010, construction started in 2011, and the site was renovated in 2018. It consists of a 60-kilowatt solar park for a single organisation, but which was originally designed to be the first 'ready-fornet metering' project (although this has never materialised). The project was funded with German development partner assistance and involved a German 
EPC contractor as the lead together with German equipment. However, the German EPC (Asantys) entered a joint venture with a local company (African Solar Designs or ASD) whose role at the SOS project was to audit and specify the system. More recently another Kenyan EPC contractor (Knight Energy and Apps Ltd) was awarded the renovation contract. Specifically, Knight Energy and Apps were involved in customer relations, planning, resource mobilisation, commissioning of the project, post installation, and maintenance of the project.

The last project studied was Kitonyoni solar plant. This project was conceived by Prof. Abubakr Bahaj, a lecturer at Southampton University, UK. The owner of the system is the Makueni County Solar Supply Co-operative Society. The project was conceived in 2012, construction started in 2012, and the park was commissioned in 2012. It is often used as a showcase project for smallscale off grid solar because of the length of time it has been running. It is a 13.5-kilowatt solar park that provides power for the local community. While it has strong local community ownership during the operation phase, the project was designed, engineered, and constructed predominately by UK engineers using a containerised 'ready-to-go' system that was put together in the UK, shipped out, and placed on site with minimal need for local construction support although a Kenyan battery supplier acted as a local partner and provided batteries for the system. The equipment used is from a range of places including the Netherlands (solar panels, charge controller, inverters); UK companies developed the mobile based payment system and provided the steel for the panel frames. As noted above, a Kenyan firm (Chloride Exide) provided locally manufactured batteries. Chloride Exide also sub-contracted another local firm (Gilgil Electrical) to work on the power distribution set up (cabling from solar park to houses).

It should be noted that while we took these projects as case studies through which to study the existence of capabilities, the analysis in the results section mostly focused on the firms involved in the projects. This is because the capabilities reside in the staff and resources of the firm and not in the projects themselves. The projects are the vehicles through which experience and capabilities are developed. As such, a firm can engage in a series of activities to build its capabilities as a result of sequential learning during the project cycle.

\section{Research results}

\section{Overview of skills and capabilities built}

An overview of the fieldwork results is presented in Table 7.2 which outlines benefits gained by each firm that was interviewed. It should be noted that the evidence of upgrading is not specifically related in all cases to the projects reviewed but as a result of general time spent in the industry. 
146 Rebecca Hanlin and Josephat Mongare Okemwa

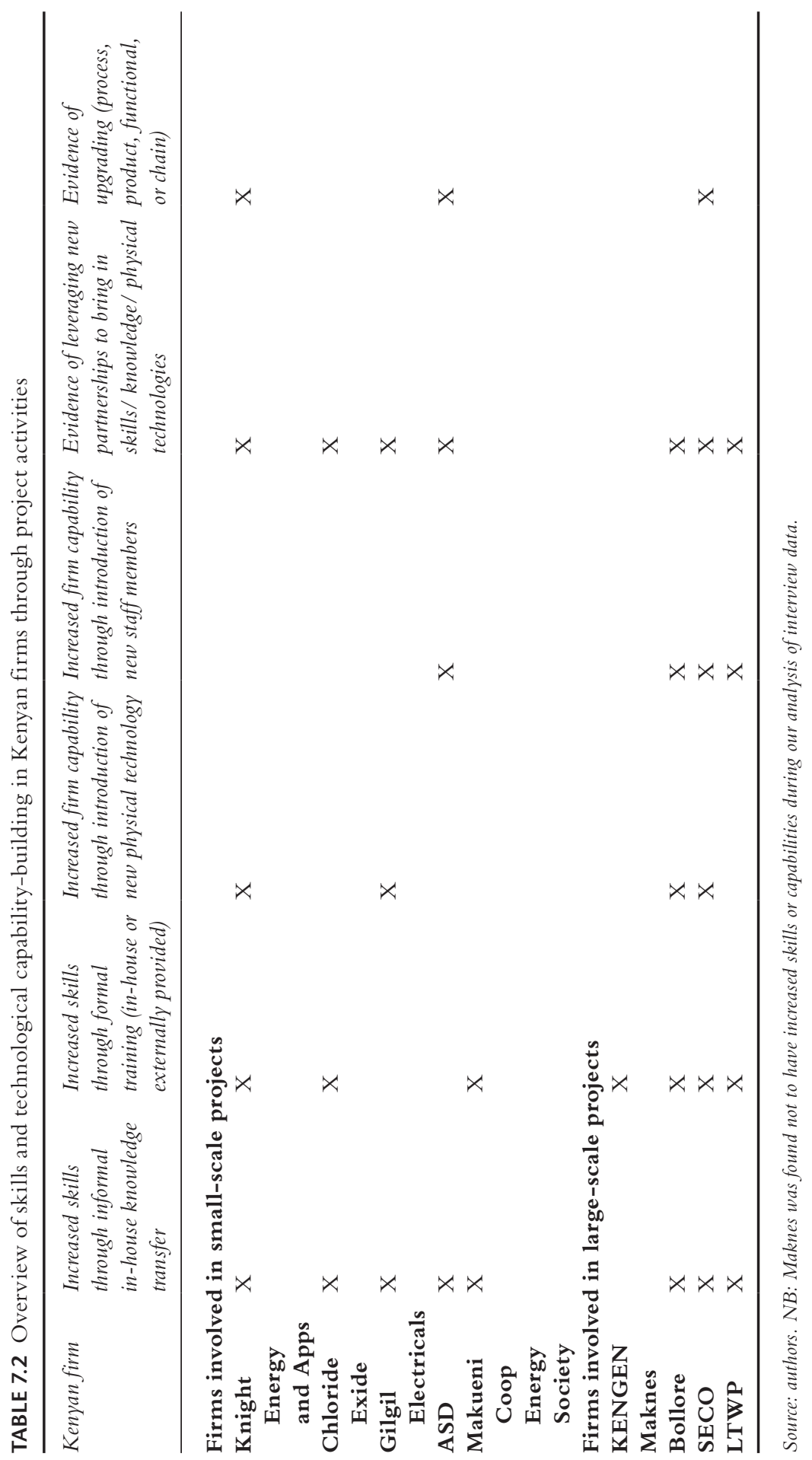




\section{Skills}

Due to Kenyan EPRA regulations the solar engineering firms all had qualified staff (always at least one per project) who had been certified to at least the minimum national standards. The same was true more generally of electrical and construction engineers who were involved in the case study projects. All of the firms interviewed and involved in the case study project sites had given training opportunities to their staff - some directly as a result of the need for new skills required for the project e.g., training to install a new inverter type or wind blade maintenance training. This was provided through in-house workshops (often where one member of staff would provide peer-to-peer feedback and training) or through formal off-site training. At times this was provided by equipment suppliers. A number of the projects provided opportunities for staff to visit other sites or the equipment manufacturers outside of Kenya. In this way they were provided with opportunities to see and learn about other contexts. That said, the majority of technicians interviewed during the fieldwork highlighted the importance of 'on the job' training which was often not formal in nature but the result of 'seeing others work' and 'sharing experiences'.

\section{Capabilities}

During fieldwork we found evidence of new physical technologies (new testing equipment for example) being introduced into firms which had resulted in new business opportunities at different stages of the project cycle. This included new IT based monitoring equipment for solar power systems and new IT data log management systems to specialist trucks and trailers. The use of imported equipment was widespread and often the choice of country of origin of the technology was due to the origin of the project finance or the links that the lead contractor(s) had already established with equipment suppliers. For the most part the use of Kenyan technology was confined to the use of consumables during project construction.

In addition to new physical technologies, firms involved in the projects studied needed to bring new knowledge into the firm. This new knowledge was bought in to exploit and develop new business opportunities at a relevant stage in the project cycle (e.g., recruitment of a staff member with EPC experience or training of existing staff in how to install a specific new invertor design). New knowledge has been a key element of the strategies of all the firms interviewed who were involved in the case studies we looked at. Joint ventures or partnerships were a key way in which new knowledge (especially from outside Kenya) was bought into a project. The new knowledge embodied in staff does not always stay at the same firm. In the case of the large wind turbine projects, we have seen a lot of staff movement across firms with project managers moving from one firm to another as projects finish and another one starts. As such, while their old firm might still work on a project, the knowledge that they have embodied within them is technically no longer available to their old firm. 


\section{Competences}

Competence building is the ability to 'coordinate diverse production skills and integrate multiple steams of technologies'. It is essentially the skill of knowing what knowledge and technologies are needed and how to integrate them. As such, in this study we looked for evidence of firms functioning as an EPC (engineering, procurement, and construction) contractor, i.e., being responsible for all elements of the project cycle until handover for operation. This is because the role of an EPC is to manage multiple stages of the project cycle in house. We also looked for evidence of the ability of firms to leverage new partnerships through their activities in these projects in order to conduct more elements of the project cycle.

We find that there is evidence of firms moving into EPC contracting while we investigated our case studies; although not specifically as a result of our project case studies - although in some cases the projects did give them added experience which they will leverage on as they built their name as EPC contractors. In some cases we find that there is what might be termed 'nested EPC' whereby one company is given an overarching EPCM contract to oversee the whole project and others are brought in to conduct different elements of the project using an EPC approach. This was true on the large-scale wind project. One of the results is a huge and complex array of partnerships built up between firms across these projects. Partnerships (some informal and others more formalised, even to the point of becoming joint ventures) are entered into so that foreign companies can get access to local knowledge and equipment/human resource already on ground. In return, local Kenyan companies receive training, skills, and can leverage further projects from the exposure they get through these partnerships. These partnerships are more complex the larger the project. The result is multiple layers of contracts and sub-contracts with multiple interactions. For example, one company is hired to do earthworks, construction, or catering by one project partner and then is asked to do the same for another project partner.

The final area where we were looking for evidence of competence building was in the area of upgrading. Upgrading strategies not only require acquisition of competences but also changing relationships with buyers in the market. Upgrading offers many opportunities to firms including increased efficiency and output in accessing new market networks as well as industrial knowledge. We found little evidence of process upgrading (e.g., increased efficiency of the installation process for example in terms of the speed or manpower requirement of an install) by local firms involved in the four case study projects. That said, two firms mentioned the introduction of new project/time management mechanisms through working on the large-scale wind project. The story of product upgrading (e.g., from using Chinese to German inverters or invertors that are deemed to be of higher quality) is more complex as we find that equipment choice was highly personal to the firms and depended on experience with a product and/or general sector optimism for a new product. We found some evidence - as noted above - of 
functional upgrading (e.g., where a firm moves from being a contractor to doing full EPC) and a small amount of evidence of chain upgrading. Again, as noted above, these last two types of upgrading are not the result of the projects themselves but a longer-term shift in company trends. Examples included one company moving from installing solar heaters to installing mini-grid systems and another company from being a mainstream automotive battery manufacturer to an active participant in solar energy mini-grid projects. We find that this takes place mostly as a result of engagement in smaller scale projects, i.e., we find very little evidence of upgrading in the two large-scale projects where companies involved are essentially doing 'business as usual'; self-reporting as such during interviews.

\section{The importance of project objectives}

As can be seen from the case study overviews, despite Kenyan ownership of the power generation plants in all four case studies, we did not see a leadership role taken by Kenyan firms at the initial stages of project design and engineering. This is the situation in the case studies with the partial exception of ASD who were partners with the German firm who were the EPC for the SOS Children's Village initial design and install. There is more Kenyan firm participation at the installation/construction phase and even more still during the operation and maintenance phase. In large projects there are service contracts involving foreign firms in both case studies.

That said, the use of Kenyan technicians and labourers is higher than was originally expected when we started this study (and higher than expected by those involved in the case studies i.e., in the case of Vestas' expectations of needing to utilise foreign engineers). In fact, we feel we could go as far as argue that the issue is not so much the technology type. This is because the level of basic skills in the engineering field is sufficient in Kenya. Instead, the issue is knowledge of the finer points of specific pieces of technology.

Thus, most capabilities-building has taken place in the installation and operations phases of the projects. Kenyan engineers have received specific training - both in Kenya and abroad - on how to utilise specific 'pieces of kit' e.g., SMA inverter systems and/or the maintenance of such kit e.g., Global Wind Organization blade repair training (especially how to work at height). Those trained in these firms have fed this training back to colleagues through in-house firm level training where appropriate. In some cases, firms have introduced new pieces of kit which enhances their technological capabilities to offer enhanced services.

As outlined in Table 7.2, while the majority of capabilities built relate to skills training, a significant level of capabilities-building has taken place across the firms interviewed in the area of leveraging new partnerships to bring in skills, knowledge, and/or physical technologies. As such, a key competence that firms involved in all the case studies are gaining more experience in is 
around partnership relations and, in the case of EPC or EPCM and/or handson owners of the plants, how to manage multiple partners. We come back to this below.

\section{Discussion}

\section{Does size and shape matter?}

Hansen et al. (this volume) found that the degree to which a project is large scale or small scale in size matters more than the shape of the project in terms of the type of technology involved in the renewable electrification project (e.g., wind vs. solar technologies). They argue that large-scale projects have a focus on EPC and turnkey solutions, predominately, by foreign firms. They did not find the same in firms working on small-scale projects. Our findings echo this but also dispute this finding somewhat. Specifically, we see that small-scale projects do provide opportunity for EPC experience for local firms and, over time, dominance in this area by local firms. However, at the same time, we find that many local firms in the LTWP manage EPC contracts but do so in a nested format, i.e., no local firm is responsible for overall project management (EPCM).

\section{Project types, specifically the focus on EPC vs. EPCM}

One of the interesting observations from this analysis of the four case studies has been the increasing opportunity for EPC roles by Kenyan firms in small solar PV plant projects. We have noted in an allied paper (Hanlin, Okemwa, and Gregersen, 2020) that this change has occurred in a relatively short time (one respondent during our study argued it had occurred in the last three years only, i.e., since 2016). It highlights a significant change from 2001 when Murphy, in a well-cited paper (Murphy, 2001), stated that the low technological capability of project managers led to the abandonment of many solar PV systems.

At the same time, we note that in the large-scale projects different models were evident. The Garissa project involved a Chinese-led EPC style of project management while the LTWP involved an adapted EPCM style of project management. In all four cases reviewed in this chapter, foreign EPC firms have played a central role either across the whole project cycle or for a significant part of the project cycle. This mirrors the finding of Hansen et al. (this volume).

Vidican (2012) noted in the case of Egyptian solar PV plant projects that having a local EPC facilitated more local company involvement in the solar PV project value chain because there was more chance that local sub-contractors would be utilised. Morris, Kaplinsky, and Kaplan (2012) also noted the same with regard to resource extraction projects in Africa, finding that where there was a local lead firm, the projects are more embedded into the local economy and are more committed to local development. 
While we do not see any cases during the initial design/engineer and install/ construction phases where there is a significant role played by local firms in any of the four cases, it must be mentioned that the LTWP did have (and maintains for operational purposes) a site and project owner who were hands-on throughout the project cycle. This owner identifies as being Kenyan and the LTWP consortium is incorporated as a Kenyan company. At the same time, this project - as opposed to our other large-scale renewable electrification project example of Garissa solar park - also involved a significant number of sub-contractors; many of which were Kenyan companies or sub-contracted Kenyan companies. The LTWP, as noted above, had a sizeable local content element to the project in terms of firm involvement.

We would argue that a key enabler for this was the type of contract that was given to the EPC firm, even though they were a foreign firm. Specifically, Worley Parsons were given an EPCM (engineer, procurement, and construction management) contract and not the usual EPC contract. The rise of the EPCM has come about as a result of the difficulty of finding a single supplier who can provide an EPC role (including bank-rolling this activity) for large-scale projects - which have a high degree of risk and uncertainty (Loots and Henchie, 2007).

Therefore we would argue that a key enabler was not just having a local hands-on owner of the project, but also that the projects specifically focused on local content clauses which included a desire to see - whether implicitly or explicitly - the use of local firms through a decision to hire a construction management firm and not one turnkey firm to conduct the whole project cycle inhouse. We have not investigated the reasons behind this in any depth during this study. It has been found elsewhere (although not in a large study) that utilising an EPCM contract has advantages over EPC forms of contract strategy in terms of enhancing the potential involvement of local suppliers in the project process (Awuzie and McDermott, 2016). It is therefore an area for further research.

This chapter took as its starting point a set of literature on project management and the role of project management as a means of enhancing work organisation and innovative activity. However, our case studies have highlighted that the question to ask isn't just over the type of project management (outlined by Brady and Hobday (2011) as matrix, functional, adhocracies, Scandinavian, or project business) but also the contractual relations involved within these project management approaches.

In investigating this issue, there appears to be a set of work around project contract types and the creation of social value through infrastructure projects (c.f. Awuzie and McDermott, 2016). Further research would be useful to interrogate the relationship between this literature and that of innovation, project management, and capabilities-building.

In addition, Loots and Henchie (2007) in their definition of the difference between an EPC and an EPCM contract note that an EPCM contract is a 'professional service contract' because the provider is not the principal. As such it is not responsible for the actual construction of the solar PV or wind generation plant. 
Vidican (2012) for example notes that in Egypt the solar PV plants she investigated required project execution capabilities as well as production capabilities and innovation capabilities. Similarly, Figueiredo and Piana (2018) specifically focus on 'knowledge intensive service' enterprises in the mining sector (e.g., geotechnical engineering firms or the environmental services firms that have a strong research and development unit). Davies and Brady (2016) therefore talk of project capabilities at the operational level and dynamic capabilities at the strategic level. Thus, recognising the importance of different types of capabilities for different elements of project management (phases and types of project management contract) appears to be more important than first expected.

There are two major implications here. Firstly, more consideration is perhaps needed as to whether certain types of project management contract should be promoted to enhance local content/involvement of more local firms. Secondly, the importance of project management and experience of EPCM project management is needed if Kenya is to stop having to rely on foreign firms to manage this activity, especially for large-scale projects.

\section{Another dimension of shape of technology: origin of technology}

One of our starting premises for the IREK project as a whole (i.e., not just this chapter) was that both large-scale projects that we studied used foreign technology; one predominately Chinese technology and the other Danish technology. For the most part this turned out to be correct. Similarly, the small-scale projects we studied we assumed would be dominated by European technology. However, we found a more complex picture in the smaller projects. Table 7.3 outlines the differences.

Despite the finding that a mix of technologies was in place, the overwhelming response received during interviews (and borne out by the fact that the projects are being implemented predominately by local Kenyan technicians and not those from the country of origin of the equipment) is that, in the case of renewable energy technologies in Kenya, the origin of the equipment isn't an issue. The

TABLE 7.3 Technology types

\begin{tabular}{lll}
\hline & Starting premise & What we found \\
\hline $\begin{array}{l}\text { Garissa } \\
\text { LTWP }\end{array}$ & $\begin{array}{l}\text { Chinese technology } \\
\text { Danish technology }\end{array}$ & $\begin{array}{l}\text { Only Chinese technology } \\
\text { Danish technology but also Chinese } \\
\text { technology and local consumables } \\
\text { Village }\end{array}$ \\
Kitonyoni & EU technology & $\begin{array}{c}\text { German technology but increasing use } \\
\text { of Chinese technology following } \\
\text { renovation } \\
\text { combination of UK, Dutch, and Kenyan } \\
\text { technology }\end{array}$ \\
\hline
\end{tabular}


reason given was the level of engineering training available in Kenya. It was considered the case that, once you learnt the underlying principles of how the technology worked, where the technology came from was not a problem. The only time this was described as an issue (and one at both the large and small scale) was when the instructions were not available in English. However, in all cases, training by the vendors of the technology was available and was given (at some point in the project or as part of general in-house capacity building by firms).

Firms in the mini-grid sector appear to prefer certain types of equipment and align with manufacturers of that equipment to receive training. For example, in the case of inverters we found a preference for European as opposed to Chinese inverters. This is little different to other sectors such as car mechanics or farming where a mechanic or farmer tends to buy a particular make of tyre or fertiliser to use either due to the cost or the customer service received from the supplier. In the case of these renewable energy firms, the reason given was the quality of the equipment.

\section{Project size and potential for capability-building}

The capability-building story has turned out to be much more complicated than expected. Our original proposition was that 'small is beautiful', i.e., that smallscale projects are more likely to be developed by indigenous owned and run firms. We also expected firms involved in the design and construction of the projects would benefit substantially in terms of skills gained and then utilise those skills in other jobs. This has not run true in all cases. The Kitonyoni project is similar to a number of other what might be called 'containerised projects' whereby stakeholders design the project, and the kit is installed with minimal local staff content. An internet search and literature review found: two more projects like this also developed by the same UK university; four containerised solutions produced and sold through an energy supplies firm in Nairobi; and at least two other containerised solutions introduced to two communities in Turkana region by a Kenyan company. It is unclear how much local ${ }^{2}$ input goes into these containerised solutions. This differs, however, from SOS Children's Village which fits our proposition and where local firms have benefited (including through upgrading) as a result of their involvement in small-scale mini-grid renewable electrification projects. However, nuances arrive when you start looking at employment figures and longer-term employment opportunities.

Based on employment figures, large-scale projects we have investigated provide - on paper - the highest opportunities for capabilities-building. For example, we were informed by interviewees from LTWP and its contractors that there was a workforce ranging from 180 to 400 people involved in the construction of the project (depending on how many sub-contractor staff are included in the calculations). The Garissa project was also found to employ around 300 people during the main construction period. As one of the EPC contractors on the LTWP project noted, many of the day labourers left the project with skills they didn't 
have before (such as carpentry or masonry skills) and which they will take with them when they leave. That said, these jobs are time bound; once the project is completed, many of these workers do not move with the contractors to the next job; especially the day labourers. Unfortunately, due to the timing of this study, whether or not they have been able to use the skills acquired in different projects or contexts has not been investigated here.

When we consider only engineers and related job positions in contractor companies working on the large sites, we find that the numbers required were much less (around 20 - mostly from Kenya; especially in the case of the Lake Turkana Wind Project). In small-scale mini-grid projects the numbers of engineers involved was less than ten in each project. In both large- and small-scale projects, engineers (as opposed to less skilled workers) were also more likely to be retained by the company after the project. We also find that engineering capability is highly mobile - with staff moving from project to project and company to company on a regular basis.

The larger projects have a high level of staff movement and a focus of project management on ensuring that sub-contractors with the knowledge required are brought into complete specific tasks within limited timeframes. This restricts the interaction with other actors; interaction is rather narrowly focused on issues of timing and avoiding budget overruns and delays. Different organisations may focus internally on building capabilities within their teams to complete their tasks rather than on more interactive types of knowledge transfer or capabilitybuilding. Future research may explore the implications of individual vs. wider organisational capability-building. At the broader macro level, questions may also be raised as to whether and how these capabilities may be diffused to future wind and solar projects. Will it be carried on through individuals, firms, or other types of organisations? Could a wider intra-organisational interaction be encouraged to ensure a wider transfer of knowledge within the innovation system for renewable energy technologies in Kenya? ${ }^{3}$

\section{What does this mean for capability-building and subsequently economic development?}

The four case studies highlight strong evidence of learning from partnerships and interactions with other firms, especially those from outside the country. As noted earlier, these case studies highlight evidence of 'learning from importing' (Haakonsson, 2009; Blalock and Veloso, 2007). These studies focus predominately on the importation of technologies (defined as physical products). These are deemed to create opportunity for new knowledge creation, result in improved productivity or reduced cost of domestic production, or change the way goods are made/what goods are made in country (Foster-McGregor and Stehrer, 2013). New knowledge creation can be within the firm receiving the technology, about how the technology works, is maintained, and how it can be utilised to improve productivity, reduce costs, or produce a new or improved 
good (Foster-McGregor and Stehrer, 2013). Alternatively, it can be arms-length knowledge spill-overs to peers in business, who see how their competitor is utilising a new piece of equipment (Bisztray, Koren, and Szeidl, 2018).

This links to a broader set of literature on how (a) linkage building is a tool for economic growth (Hirschman, 1981) and (b) technology transfer is beneficial to firm performance and therefore economic performance of countries - what is known as 'technology gap theory' (Fernandez and Gavilanes, 2017; Coe and Helpman, 1995). An increasing focus on developing countries achieving economic growth through innovation is based on the idea that they will innovate new technologies (Zanello et al., 2016). However, fundamental innovation of radical new technologies is difficult for developing countries because of a lack of absorptive capacity (skills and knowledge) plus often social, economic, and political conditions that are not conducive, which means institutional arrangements are insufficient. The result is that 'external sources of technology account for a large component of productivity growth in most developing countries' (Zanello et al., 2016, p. 2). Therefore, what is put forward as being needed is to tap into 'existing knowledge and know-how from foreign countries' or to 'facilitate the exchange of both external and local knowledge within a country' (Zanello et al., 2016).

The learning from importing that we are seeing in these case studies is not simply related to what is available through a 'piece of kit' - what Haakonsson and Slepniov (2018) have discussed as 'learning by suppliers' through 'technology transmission'. It is more congruent with a broader definition of technology as outlined above - as embodied in a physical entity but also defined as skills, knowledge, and know-how. It also highlights the importance - in the context of the discussions of the type of technology and knowledge that is important for economic growth - of these linkages and interactions that are playing out on the ground in these case studies.

In fact, it might be that these case studies are not so much about learning from importing as much as about the importance of learning through interacting. It reiterates the importance from a policy perspective of encouraging linkages between diverse groups of actors in a supply chain and providing appropriate incentives. Haakonsson (2009) highlighted the importance of joint ventures and foreign investors' role in promoting upgrading through upstream linkages with suppliers in the Ugandan pharmaceutical industry. Haakonsson and Slepniov (2018) note the importance of local content and import substitution policies in China on technology upgrading in the Chinese wind turbine industry. Hanlin and Hanlin (2012) highlight the importance of 'facilitatory policy' such as local content rules relating to procurement of goods (not just employment of local staff) in the mining industry in Tanzania and the Democratic Republic of Congo. Our four case studies are in Kenya, and Kenya has different contextual situations in which businesses work compared to Uganda, Tanzania, Democratic Republic of Congo, and China, however, the importance of linkages promotion by government policy cannot be downplayed. 


\section{Conclusion}

The case studies we have examined in this chapter highlight the importance of a set of 'base skills' and educational standards which allows more opportunity for Kenyan firms to benefit and build capabilities and competencies. It also highlights the important role of linkages - whether as formal contractual partnerships or more informal exchanges or linkages. Providing the right policy on capabilities-building is crucial for the promotion of a continued set of base skills and educational standards as well as promotion of linkage opportunities.

The case studies reveal that a firm can engage in a series of activities to build its capabilities; it can engage in sequential learning through a project cycle. The case studies also highlight that what is important, from a policy perspective, is not so much the learning that can occur from importing technology but the importance of learning through interacting with project partners, including those from outside the country. This has important implications for policy on the export-oriented sustainable industrialisation path which a country may want to take.

Specifically, the findings of this study of four different sized and technology focused projects highlight that a range of capabilities can - and should - be built. Perhaps the most important are those relating to project management - the dynamic capabilities at the strategic level as noted by Davies and Brady (2016). In particular, the study highlights the importance that needs to be given to researching and understanding the difference between EPC and EPCM contract types and the skills and capabilities needed to manage these. This dovetails the results of our first research question on the type of capabilities that are important with our second research question on how the design and management of a project matters. Design and management of a project matter, and therefore firms must have the capabilities at this level and not just ordinary capabilities at the project operation level.

\section{Acknowledgements}

Support for research on which this chapter is based from the Danish Ministry of Foreign Affairs, Grant: DFC 14-09AAU is gratefully acknowledged. We also acknowledge all the interviewees and reviewers of this chapter during IREK project meetings.

\section{Notes}

1 An EPCM contract follows the EPC contract style but differs in that the same firm is also in charge of project management.

2 We note - as Gregersen (2020) does elsewhere - that there are different definitions of 'local' i.e., local to the surrounding area and local as in within national boundaries plus a series of options in between. The lack of information about who is providing what and from where (a general finding throughout the IREK project under which 
this study was undertaken) is a key hindrance in developing a clear understanding of what capabilities are being built and by whom.

3 We are grateful to discussions with a co-author, Cecilia Gregersen, of a working paper (Hanlin et al., 2020) on which this chapter is based, for helping us think through the development of these questions for future research.

\section{References}

Africa Renewable Energy Initiative (2016) AREI Action Plan. [Online]. Available at: http://www.arei.org/wp-content/uploads/2018/03/AREI-Action-Plan-Nov-2016 .pdf. (Accessed: 30/08/2020).

Andersen, M.H., Lema, R., Hanlin, R., Tigabu, A. and Kingiri, A. (2017) Collaboration and Capabilities in Kenya's Wind and Solar Industries: Perception of Stakeholders. IREK Report number 3 [Online]. Available at: https://www.irekproject.net/portfolio/re port3/ (Accessed: 11/06/ 2020).

Archibugi, D. and Coco, A. (2005) 'Measuring technological capabilities at the country level: A survey and a menu for choice' Research Policy, 34, pp. 175-194. https://doi.org /10.1016/j.respol.2004.12.002

Awuzie, B.O. and McDermott, P. (2016) 'The role of contracting strategies in social value implementation', Proceedings of the ICE-Management, Procurement and Law, 169(3), pp. 106-114.

Bell, M. (2009) Innovation Capabilities and Directions of Development, STEPS working paper 33. Brighton: STEPS Centre.

Bisztray, M., Koren, M. and Szeidl, A. (2018) 'Learning to import from your peers', Journal of International Economics, 115, pp. 242-258. https://doi.org/10.1016/j.jinteco .2018.09.010

Blalock, G. and Veloso, F.M. (2007) 'Imports, productivity growth, and supply chain learning', World Development, 35(7), pp. 1134-1151. https://doi.org/10.1016/j.worl ddev.2006.10.009

Brady, T. and Hobday, M. (2011) 'Projects and innovation: Innovation and projects' in: Morris, P.W., Pinto, J.K. and Söderlund, J. (eds.) (2011) The Oxford Handbook of Project Management. Oxford: Oxford University Press.

Calderon, C. and Serven, L. (2010) 'Infrastructure and economic development in SubSaharan Africa', Journal of African Economies, 19, pp. i13-i87. https://doi.org/10.1093 /jae/ejp022

Coe, D.T. and Helpman, E. (1995) 'International R\&D spillovers', European Economic Review, 39(5), pp. 829-859. https://doi.org/10.1016/0014-2921(94)00100-E

Davies, A. and Brady, T. (2016) 'Explicating the dynamics of project capabilities', International Journal of Project Management, 34(2), pp. 314-327. https://doi.org/10.1016 /j.ijproman.2015.04.006

Démurger, S. (2001) 'Infrastructure development and economic growth: An explanation for regional disparities in China?', Journal of Comparative Economics 29, pp. 95-117. https://doi.org/10.1006/jcec.2000.1693

Farlam, P. (2005) 'Working together: Assessing public-private partnerships in Africa. The South African Institute of International Affairs'. [Online]. Available at: https ://www.oecd.org/investment/investmentfordevelopment/34867724.pdf (Accessed: 05/06/2020).

Fernández, J. and Gavilanes, J.C. (2017) 'Learning-by-importing in emerging innovation systems: evidence from Ecuador', The Journal of International Trade \& 
Economic Development, 26(1), pp. 45-64. https://doi.org/10.1080/09638199.2016.12 05121

Figueiredo, P.N. and Piana, J. (2018) 'Innovative capability building and learning linkages in knowledge-intensive service SMEs in Brazil's mining industry', Resources Policy, 58, pp. 21-33. https://doi.org/10.1016/j.resourpol.2017.10.012

Flyvbjerg, B. (2006) 'Five misunderstandings about case-study research', Qualitative inquiry, 12(2), pp. 219-245. https://doi.org/10.1177/1077800405284363

Foster-McGregor, N., and Stehrer, R. (2013) 'Value added content of trade: A comprehensive approach', Economics Letters, 120(2), pp. 354-357. https://doi.org/10.1 016/j.econlet.2013.05.003

Government of the Republic of Kenya (2007) Kenya Vision 2030. Nairobi: Government of Kenya.

Gregersen, C. (2020) 'Dynamic sublimes as drivers of a Kenyan renewable energy megaproject' in: Paper presented at the DRUID Academy Conference 2019 at Aalborg University, Denmark, January 16-18, 2019. [Online]. Available at: https:// conference.druid.dk/acc_papers/17gmx4987wjkyqke4epbpvs421fk0h.pdf (Accessed: 06/06/2020).

Haakonsson, S.J. (2009) “Learning by importing” in global value chains: upgrading and South-South strategies in the Ugandan pharmaceutical industry', Development Southern Africa, 26(3), pp. 499-516. https://doi.org/10.1080/03768350903086861

Haakonsson, S.J. and Slepniov, D. (2018) 'Technology transmission across national innovation systems: The role of Danish suppliers in upgrading the wind energy industry in China', European Journal of Development Research, 30(3), pp. 462-480. https ://doi.org/10.1057/s41287-018-0128-5

Hanlin, R. and Hanlin, C. (2012) 'The view from below: 'Lock-in' and local procurement in the African gold mining sector', Resources Policy, 37(4), pp. 468-474. https://doi .org/10.1016/j.resourpol.2012.06.005

Hanlin, R., Okemwa, J. and Gregersen, C. (2020) Building Competences and Capabilities through Projects: Examples from Kenya's Renewable Energy Sector, IREK Working Paper 8. [Online]. Available at: http://irekproject.net (Accessed: 06/06/2020).

Hansen, U.E. and Ockwell, D. (2014) 'Learning and technological capability building in emerging economies: The case of the biomass power equipment industry in Malaysia, Technovation, 34(10), pp. 617-630. https://doi.org/10.1016/j.technovation.2014.07.003

Hirschman, A.O. (1981) Essays in Trespassing: Economics to Politics and Beyond. New York: Cambridge University Press.

Hoka, H., Njogu, H. and Obiero, B. (2018) Realising the Big Four Agenda. Nairobi: KIPPRA Working Paper.

Khandker, S.R., Bakht, Z. and Koolwal, G.B. (2009) 'The poverty impact of rural roads: Evidence from Bangladesh', Economic Development and Cultural Change, 57, pp. 685722. https://doi.org/10.1086/598765

Lall, S. (1994) 'Technological capabilities' in: Solomon, J.J. et al. (eds.) The Uncertain Quest: Science, Technology and Development. Tokyo: UN University Press.

Liu, X., Hotchkiss, D.R. and Bose, S. (2008) 'The effectiveness of contracting-out primary health care services in developing countries: a review of the evidence', Health policy and planning, 23(1), pp. 1-13. https://doi.org/10.1093/heapol/czm042

Loots, P. and Henchie, N. (2007) 'Worlds apart: EPC and EPCM contracts: Risk issues and allocation', International Construction Law Review, 24 (1/4), p. 252.

Morris, M., Kaplinsky, R. and Kaplan, D. (2012) 'One thing leads to another: Commodities, linkages and industrial development', Resource Policy 37(4), pp. 408416. https://doi.org/10.1016/j.resourpol.2012.06.008 
Murphy, J.T. (2001) 'Making the energy transition in rural East Africa: Is leapfrogging an alternative?', Technological Forecasting and Social Change, 68(2), pp. 173-193. https:/ /doi.org/10.1016/S0040-1625(99)00091-8

Srinivas, S. and Sutz, J. (2006) Economic Development and Innovation Problem-solving in Scarcity Conditions. CID Graduate Student and Postdoctoral Fellow Working Paper number 13, Sustainability Science program. Cambridge, MA: Center for International Development, Harvard University.

Vidican, G. (2012) 'Building domestic capabilities in renewable energy: A case study of Egypt', German Development Institute Studies Series, 66. Bonn: Deutsches Institut für Entwicklungspolitik (DIE). ISBN 978-3-88985-503-9.

Zanello, G., Fu, X., Mohnen, P. and Ventresca, M. (2016) 'The creation and diffusion of innovation in developing countries: A systematic literature review', Journal of Economic Surveys, 30(5), pp. 884-912. https://doi.org/10.1111/joes.12126. 